\title{
On Agency and Ramparts in the Lower Danube and Spain
}

\section{Adriaan DE MAN}

\begin{abstract}
Having worked mainly on the late Roman and Visigothic walls of the Spanish provinces, I came across the details of Dacian-Moesian frontier defences mostly by chance, through a book by Carl Schuchhardt and his contributions to linear earthworks. I would like to contrast these valla in the specific angle of agency, as the discussions on the Moldovan wall of Athanaric and its chronology are reminiscent of questions posed as well in southwestern imperial contexts. Although no precise equivalences for such extensive, often river-connected ramparts are known in Hispania, I wish to put a few points in perspective and to establish some not strictly archaeological, but rather interpretive correspondences. The purpose is framing a meta-analysis for early Gothic defensive concerns, with a focus on large built structures, from the standpoint of their perceived usefulness, as a trigger for agency. The cultural reality of both territories in contrast is entirely distinct, and may therefore provide an interesting approach for the understanding of investment priorities in the genesis of very early medieval monarchies, and their negotiated implementation through transformed imperial mechanisms. Again, this evolved on radically separate realities. In a Danubian setting, one observes a frontier retraction associated with the political survival of the eastern empire; contrariwise, in Spain, a power substitution succeeded only through permanent negotiation with local and regional authorities. The text below takes this into account, yet looks explicitly at the reactive dimension, which was presumably pre-emptive and symbolic as well, of post-imperial embankments, walls, and other forms of linear defence.
\end{abstract}

Keywords: late antiquity, sponsorship, valla, comparative History, Gothic administration.

\section{Framework and background}

The story behind the identification of a sequence of connected earthworks in Moldova, articulated with the local orography, namely the Siret and the Prut rivers, owes much to the late $19^{\text {th }}$ century scrutiny into a presumed imperial origin $^{1}$, and emerges in the context of a wider analysis on linear fortifications in the area $^{2}$. This did make sense from the perspective of a generic frontier-

1 Carl Schuchhardt. "Wälle und Chausseen im südlichen und östlichen Dacien," Archäologisch-Epigraphische Mittheilungen aus Österreich 9 (1885): 202-232.

2 Richard Mason and Costin Croitoru. Carl Schuchhardt's Contributions on Ancient Linear Fortifications along the Lower Danube (Cluj-Napoca: Mega, 2016). 
based defence, hence an old and inappropriate Trajanian designation for this southern Bessarabian vallum. No fact actually supports the traditional ascription to Trajan's Dacian campaigns, but many of the large fortifications on the limes Moesiae are to be considered as part of later Roman military strategic options, as patently are the nearby Constantinian barriers defending Dacia ${ }^{3}$. The southern Moldovan vallum is however located on the opposite bank of the Prut, and does therefore not articulate well with the sections between the Prut and the Dniester, and more southwards, in the area of Constanța in modern Romania. Subsequent studies indeed led to a more detailed understanding of subsections, and, at least since Vulpe ${ }^{4}$, taking the structure as a so-called Athanaric's wall became a reasonable premise. In short, these embankments would constitute tangible proof of Ammianus Marcellinus on the 375-6 Hunnic assaults on Gothic territory (31.3.7): Athanaricus, troubled by this unexpected attack and still more through fear of what might come, had walls built high, skirting the lands of the Taifali from the banks of the river Gerasus as far as the Danube, thinking that by this hastily but diligently constructed barrier his security and safety would be assured ${ }^{5}$. If today's surviving text of Ammianus is to be taken literally, the expression ad usque Danubium would need to be understood as a vague direction, given that the physical structure itself ends on the Prut, as correctly pointed out by Tappe ${ }^{6}$. Antoche and Tanasache assumed that, out of all the ramparts in the region, the only section that might correspond to the description is located between the village of Ploscuțeni, on the Siret, and that of Stoicani, on the Prut ${ }^{7}$. More recent observations ${ }^{8}$ assist in tracing and refining precise locations of this vallum, but a reasonably cautious working hypothesis requires very broad chronological brackets.

3 Eugen Teodor and Magdalena Ştefan. "Landscape archaeology along Limes Transalutanus." Journal of Ancient History and Archaeology 1, no. 3 (2014): 31-43.

4 Radu Vulpe. Le vallum de Moldavie Inférieure et le "mur" d'Athanaric (Den Haag: Mouton \& Co, 1957); Radu Vulpe. "Les valla de la Valachie, de la Basse-Moldavie et du Boudjak," in Actes du IXe Congres international d'études sur les frontiers romains, ed. D. M. Pippidi (Bucuresti / Köln: Editura Academiei / Bölau Verlag, 1974), 267-276.

5 John Carew Rolfe. Ammianus Marcellinus, History, Volume III, Books 27-31. Excerpta Valesiana, Loeb Classical Library 331 (Cambridge: Harvard University Press, 1939).

6 Eric Ditmar Tappe. "Le Vallum de la Moldavie Inférieure et le Mur d'Athanaric. By R. Vulpe," Slavonic and East European Review 37 (1958): 314.

7 Antoche, Constantin and Tanasache, Marcel."Le vallum (Troian) de la Moldavie centrale." Etudes Roumaines et Aroumaines, Sociétés européennes 8, (Paris \& Bucarest, 1990).

8 Richard Mason and Lucas Mason. "Unrecognized Remains of the Western Segment of the Ploscuțeni-Stoicani Vallum (Athanaric's Wall) East of Ploscuțeni (Vrancea County, Romania)," in Ancient Linear Fortifications on the Lower Danube (Cluj-Napoca: Mega, 2014): 27-40. 
This uncertainty on the dating of large defensive structures strongly resonates in radically different, albeit Roman geographies. Moesian security challenges, for instance, had little to do with those of Hispania, except for some general administrative resemblances. As a matter of fact, the first remark needs to face the inexistence of broad-spectrum military strategies in the Roman world, and a mosaic of regional solutions had always been the norm instead. This goes against some older literature that looks at the Roman empire in a sort of equivalence to modern militaries, following an alleged grand strategy (Luttwak is a fine example ${ }^{9}$ ) which is both anachronistic and would have been technically unreasonable and unmanageable anyway. Another not very recent but convenient source on the defences of Dacia ${ }^{10}$ illustrates the interlaced nature of landscape and threats of Pannonian, Dacian and Moesian military integrations in full. They are only vaguely evocative of the mainly regional and low density operations encountered in Hispania, where initial Vandal and Suevic engagements were manipulated, and sometimes directly supported, by quite consistent legionary expeditions. These, and in later years also Gothic campaigns were conditioned not only by distance and topography, but fundamentally by the strength of social cohesiveness connected to regional landownership ${ }^{11}$, which greatly determined the degree of need for additional investment in physical defences. The second notion is that of continuities, abandonments, and reuses of both concepts and structures during late antiquity, even when literary summaries may indicate very abrupt shifts. One such source is the $7^{\text {th }}$ century interpretation of Isidore of Seville, according to whom Athanaric founded his kingdom in faraway Dacia (Hist. Goth. 6: [the Hispanic, not the AD] Aera CDVII, anno $V$ imperii Valentis; i.e. 369), later to prosper on the Spanish territories. This link between both extremes of the Roman world is certainly debatable, and nothing in the primitive Gothic monarchies, be it in Spain or in Dacia, prompted modular transformations in defensive architecture. In practice, each monumental defence evolved according to local factors, often merely topographic in nature, which invalidates any pretension of rigid systematization. A regionalization in policing and defence based on episcopal and comital irregular forces becomes quite well perceptible in transitions between the house of Constantine and the reality transpiring in the later Visigothic law codes (e.g. Lex Wisig. 9.2.68). This is a rather complex evolution that entails much intricacy and deserves

9 Edward Luttwak. The grand strategy of the Roman Empire: from the first century CE to the third (Baltimore: Johns Hopkins University Press, 1976).

${ }^{10}$ Nicolae Gudea, “The Defensive System of Roman Dacia.” Britannia 10 (1979): 63-87.

${ }^{11}$ Adriaan De Man. "The locus in the context of late antique Spain." Journal of Ancient History and Archaeology 7, no. 4 (2020): 52-57. 
more detailed discussions, but for the purpose of this paper it bears a question on the promotion of large, costly investments such as defensive structures. Two Hispanic examples may serve as food for thought in this comparative perspective, as they too suffer from later historical contaminations, in a similar way to that of the term Trojan, which has acquired a wealth of toponymical and legendary survivals in the Moldovan region ${ }^{12}$.

The first and probably the most illustrative of such examples is the Cava de Viriato in Viseu, the Roman city of Vissaium, then the Visigothic bishopric of Beseo, and later a regional frontier strongpoint between Christians and Muslims. A large defensive rampart, at the outskirts of the city itself, was built at an undetermined point in time, and configures an extensive vallum that nowadays reaches more than $4 \mathrm{~m}$ in height, with a $4 \mathrm{~m}$ deep, 7 to $8 \mathrm{~m}$ wide ditch. Traditionally considered from the Roman period, in the $17^{\text {th }}$ century it acquired a fabled connection with the Lusitanian chieftain Viriatus, who led a rebellion against Roman administration, and ultimately became a nationalistic figure the likes of Vercingetorix, Ambiorix, or Boudica. Ever since, the discussion has attracted plenty of attention, and provided inconclusive options between the Roman republican and the medieval periods (a short selection includes Girão ${ }^{13}$, Mantas ${ }^{14}$, Vaz ${ }^{15}$, Alarcão ${ }^{16}$, and Catarino ${ }^{17}$ ). One main issue is that, despite several excavations along different parts of the vallum, no datable material was retrieved, apart from a few fragments of scattered coarse ware, and a hydraulic connection that would have allowed for regulating the water level. A recent text insists on the possibility of a medieval "failed city", purportedly initiated, then quickly abandoned ${ }^{18}$, yet the proportions and es-

${ }^{12}$ Costin Croitoru. “The "Trojan” in the Romanian Oral Tradition." Ancient Linear Fortifications on the Lower Danube (Cluj-Napoca: Mega, 2014): 99-110.

${ }^{13}$ Amorim Girão. “Cava de Viriato. Novos elementos para a sua interpretação.” Beira Alta III, 1 (1944): 69-75.

${ }^{14}$ Vasco Mantas. “Indícios de Campo Romano na Cava de Viriato?.” Al-Madan II,12 (2003): 40-42.

${ }^{15}$ Joao Ines Vaz. “A Cava de Viriato num documento do século XVII.” Conimbriga 45 (2006): 199-209.

${ }^{16}$ Jorge Alarcão. “Notas de arqueologia, epigrafia e toponímia IV,” Revista Portuguesa de Arqueologia 9, no. 1 (2006): 131-147.

${ }^{17}$ Helena Catarino. "A Marca inferior em Portugal na época de Almansor: hipóteses de trabalho e os exemplos de Viseu e Coimbra." in La Península Ibérica al filo del año 1000. Congreso Internacional Almanzor y su época, ed. José Luis del Pino García (Córdoba: Fundación Prasa, 2008): 123-146.

${ }^{18}$ Manuel Real and Catarina Tente. “A Cava de Viriato - novos dados e interpretações.” Do Império ao Reino. Viseu e o território entre os séculos IV a XII, ed. Catarina Tente Viseu: Câmara Municipal, 2018): 121-129. 
pecially the measurements of the fortification correspond exactly to Roman units: its thickness of $35 \mathrm{~m}$ is 1 actus or 120 feet, while the internal diameter is $706 \mathrm{~m}$, meaning 20 actus or 2400 feet, and the exterior perimeter is $2960 \mathrm{~m}$, or about 2 Roman miles. This is a clear procedure in centuriations and other land surveys, visible in parcels such as the iugerum and the centuria quadrata. These metric observations were published in a short, important paper ${ }^{19}$ that concludes not necessarily for the Roman nature of the vallum, as the same traditions might have persisted throughout slightly later times.

Far from the Danubian and Rhenanian frontiers, and their specific threats, Visigothic walls in Spain, usually with but sometimes without vallum, have been looked upon as essentially urban in nature, and it is true that a number of such defences were not merely late imperial reconversions, but new building programs under indirect (e.g. at Merida) or direct (as in Recopolis) royal authority. The former example is an interesting case of reconversion and rebuilding by order of the Visigothic governor Salla, in conjunction with the local bishop, while the latter is an ex novo creation, within an ample scenario of kingly investment, namely in early medieval central Iberia ${ }^{20}$. External pressure being caused not by invading Huns, but limited to more or less occasional initiatives from the continental side, early medieval non-urban, territorial fortifications were installed or rehabilitated mainly in Tarraconensis, along the passages through the Pyrenees (e.g. hilltops sites and full clausura systems such as Puig Rom, Les Cluses, Sant Vicenç d'Enclar, among others ${ }^{21}$ ). The other major territorial opposition consisted of a short-lived but considerably robust Justinianian expansion into the south-eastern regions. There are some markers of fortification efforts there, yet mainly in a strategy of a limes control, based not on linear defences but on border cities and their territories. The main difference with the mountain clausurae was conceivably geomorphic, associated with a perspective of low-scale military engagements, which indeed ended up being the case for a few decades: "Byzantine" coastal cities were only nominally considered as such, because of the mercenaries stationed there by the empire, and the corresponding Greek military administration. Regardless, the Pyrenaic clausura lines were not exclusively mountain gorge closures, as was

${ }^{19}$ Rodrigo Banha Silva. “De Volta à “Cava de Viriato” (Viseu).” Al-Madan II, 17 (2012): 163-164.

${ }^{20}$ Lauro Olmo Enciso. "The Materiality of Complex Landscapes: central Iberia during 6th8th centuries A.D.” New Directions in Early Medieval European Archaeology: Spain and Italy Compared. Essays for Riccardo Francovich, ed. Sauro Gelichi and Richard Hodges (Turnhout: Brill, 2015): 15-42.

${ }^{21}$ Cristina Godoy Fernández. "Archaeology in the eastern part of the Tarraconensis province in the times of the Visigothic kings," Catalan Historical Review 13 (2020): 9-25. 
the case in the neighbouring Alps and Atlas realities, but composed of linear stone walls built as well in the lowlands that provided access to the mountains, a reality recognized for a long time now ${ }^{22}$.

\section{Agency and its effects}

In this handful of cases, it is agency, more than technology, that may be compared with Athanaric's wall. In other words, the material outcomes of Gothic authority and patronage regarding defensive investment is reactive, and builds on a precise territory, with its own imperial pre-existences, traditions, and perceived threats. Agency here needs to revolve around the relationships between individuals (Visigothic kings, governors, and so forth) and structures (not only tangible but especially social ones), in the sense that the latter condition the former through situational perceptions and beliefs, thus limiting the variety of practical choices. In short, social construction as much as any physical one would have prompted specific action and response by Gothic leadership, and it is not sufficient to enunciate Hunnic or Roman military positions on a map, especially as these would also have to be seen in the light of agency theory. Some good early syntheses on this academic approach can be found in Dobres and $\mathrm{Robb}^{23}$ or Dornan ${ }^{24}$, together with the most recent revival of academic discussions around agency, on criticism of New Materialism ${ }^{25}$, on post-processual non-human, or object-based agency ${ }^{26}$, or on the connections between agency and digital archaeology ${ }^{27}$. The interpretation given to agency in this paper is a straightforward classical one, perhaps largely back to the simple centrality of Bourdieu's habitus, that is to say, to the unconscious constraint of the agent by his social structures. In other words, the promoter of a defensive structure in Spain or Dacia acts according to his "known knowns" only, and is motivated by a system that presents him with what he reasonably perceives as a limited set of choices. The inherent limitations in archaeological interpretations, such as the ones on Visigothic rampart building, require the combination of some

${ }^{22}$ Alberto Balil, “La defensa de Hispania en el Bajo Imperio.” Zephyrus 11 (1960): 179-197.

${ }^{23}$ Marcia-Ann Dobres and John Robb, Agency in Archaeology (London: Routledge, 2000).

${ }^{24}$ Jennifer Dornan, "Agency and Archaeology: Past, Present, and Future Directions." Journal of Archaeological Method and Theory 9, no 4 (2002): 303-329.

${ }^{25}$ Artur Ribeiro. "Archaeology and the New Metaphysical Dogmas: Comments on Ontologies and Reality." Forum Kritische Archäologie 8 (2019): 25-38.

${ }^{26}$ Astrid van Oyen, "Material Agency.” The Encyclopaedia of Archaeological Sciences, ed. Sandra López-Varela and Julian Thomas (Chichester: Wiley Blackwell, 2018), 1-5.

${ }^{27}$ Lorna-Jane Richardson and Simon Lindgren. "Online tribes and digital authority: what can social theory bring to digital archaeology?” Open Archaeology 3, no. 1 (2017): 139-148. 
by now conventional references on social groups ${ }^{28}$ and on singular intentionality within cultural contexts, or "micro-processes" 29 , making it so that the individual is more than a mere passive product of his circumstances, and rather acts according to different levels of acquired norms within a collective whole. This becomes clear when certain of these levels do not align between interpretations on Athanaric and other Goths, and their relationship with Romans, in Ammianus Marcellinus, Cassiodorus, or Jordanes ${ }^{30}$, not all due to literary specificities or access to factual sources. On the other hand, a seemingly unambiguous effect such as defensive construction in the wake of a Hunnic attack is most probably not a linear equation either, as it calls for not only a variety of unknowns, but above all for the proper understanding of the agent (both individual and collective) and his sociological boundaries.

This presents natural relationships with the material effects of Gothic agency, i.e. the investment in large public works such as permanent walls and valla. Whereas extensive linear retractions from the later eastern empire, such as the Anastasian Long Wall, functioned appropriately on occasion, in a certain sense they may be seen, in this geography, as a prelude to what has been called the Great Age of Walls ${ }^{31}$, not to mention the fact that they follow a pattern which is quite common in other Roman frontier realities. As it happens, there was furthermore little appetite for structural disruption in late antiquity. The Gothic monarchies did retain many of the existing legal obligations, namely the munera system that had been wittingly put into practice for the construction of defensive walls (e. g. C. Th. 15.1.49, from the year 412, according to which all, no matter their condition, were forced to work for these rampart building programs). This is in full alignment with the several Theodosian regulations forcing citizens to participate in the fortification works, under imperial supervision, following less universal public requirements about the need to work on the appropriately called munera sordida, already since the mid- $3^{\text {rd }}$ century $^{32}$. Still in Gothic Spain, where no massive linear defences are traceable, the continued tradition of putting local populations to

${ }^{28}$ Michael Shanks and Christopher Tilley, Re-constructing Archaeology: Theory and Practice (London: Routledge, 1987).

${ }^{29}$ Ian Hodder, "Agency and individuals in long-term processes." Agency in Archaeology, ed. Marcia-Ann Dobres and John Robb, London: Routledge, 2000): 21-33.

${ }^{30}$ Arne Søby Christensen. Cassiodorus, Jordanes and the History of the Goths: Studies in a Migration Myth (Copenhagen: Museum Tusculanum Press, 2002).

${ }^{31}$ David Frye. Walls: A History of Civilization in Blood and Brick (New York: Scribner, 2018).

${ }^{32}$ Adriaan De Man. Defesas Urbanas Tardias na Lusitânia. Studia Lusitana 6 (Mérida: Museo Nacional de Arte Romano, 2011). 
work on city walls and other public infrastructures is very noticeable, as, for instance, was the case under Swinthila (Hist. Goth. 63). In addition to this specifically Spanish reference by Isidore, the practice is clearly ubiquitous and deep-rooted, given the straightforward directives by Cassiodorus on the mandatory civilian participation in the digging of ditches and the building of fortifications; it is worthwhile remarking that both his father and himself had a direct notion of the Hunnic reality. Now, Athanaric the Visigoth's authority was not that of the later kings of Gothic Spain, and of Cassiodorus and Theodoric the Great, and he certainly does never appear as a king in Jordanes and Ammianus Marcellinus ${ }^{33}$, but rather as a "judge" of the Goths and, towards the end of his power, acting as a reiks of a reduced group or clan, before dying in Constantinople in a very diminished position.

The idea of a kingly conditor is to some degree present in the action of all Gothic rulers, in a clear attempt of association with forms of imperial authority. Until the mid-6th century at least, there is massive descriptive, albeit often anecdotic evidence on Gothic kings acting as if they were not equivalent to an emperor, but rather to high-ranking Roman governors, including through cultural, visual, and leisure practices that seem to differ little from those of great imperial noblemen ${ }^{34}$, and included the corresponding military obligations in equally similar formats. For Spain, John of Biclar ${ }^{35}$ refers defensive building programs precisely under Leovigild, including massive Visigothic fortified lines against the Sueves and the indigenous populations of the northwest. These do not actually configure continuously linear structures, yet instead an articulated control over sequential hilltops and roads. At this point in time, the mid- $6^{\text {th }}$ century that is, agency and sponsorship are clearly centralized on the figure of the king. During the preceding hundred years, there is a case to be made for the defensive investment by imperial contingents, at least until the last attempts to secure some sort of military relevance in the Spanish provinces, which coincide with a final unsuccessful offensive under Majorian in 460. In the Dacian situation, a much earlier foedus with the Tervingi had led to a very temporary degree of normalcy that ultimately ended with the last campaigns of Valens, and then the Hunnic expansion. Archaeological evidence points at occasional late garrison maintenances and at

\footnotetext{
${ }^{33}$ Herwig Wolfram. "Athanaric the Visigoth: monarchy or judgeship. A study in comparative history," Journal of Medieval History 1 (1975): 259-278.

${ }^{34}$ P. S. Barnwell, Emperor, Prefects \& Kings: The Roman West, 395-565 (Chapel Hill: University of North Carolina Press, 1992).

${ }^{35}$ Joan Rowe Ferry. John of Biclar and his "Chronicle" (Spain) (Houston: Rice University, 1990).
} 
least partial reoccupation of a few rebuilt forts ${ }^{36}$, and there is sporadic late $4^{\text {th }}$ and early $5^{\text {th }}$ centuries coin circulation in the region ${ }^{37}$, but it is not even clear who in fact were the agents here, and it is safe to state that the empire had definitely retracted.

In both realities, post-Constantinian investment would point towards Gothic chronologies, but also the Theodosian order was very concerned with imperial defences, not only in strict pragmatic terms, yet in an expression of dynastic affirmation as well ${ }^{38}$. In the Spanish case, this meant a continued support on large fortified cities and their territories, on which the Visigoths largely constructed an unstable network of loyalties. The monarchy, especially since Leovigild's reign, would maintain a clear distinction between duces and rectores provinciae, in an almost linear extension of the Roman system ${ }^{39}$. Indeed, imperial norms of the second half of the $4^{\text {th }}$ century (e.g. C. Th. 15.1.15 or 15.1.35) had made ample reference to the duties of said rectores, or civilian governors, invariably on matters of (defensive) construction and maintenance. On its turn, the teloneum episcopi ${ }^{40}$, as a tax levied by the bishop, overlapping the late imperial annonary circuits, reveals a recalibration of local powers stemming from the weakening of central power, correlated with the emergence of regional defence structures. The recurrent Visigothic incapacity in organizing a cohesive security policy in fact led very steadily to a decentralization in terms of security, in personal, casuistic formats that ensured power in precarium, that is on the basis of permanent nominal revocation ${ }^{41}$. It is clear that the recurrent security outcomes consisted of random actions by local Visigothic comites, and financial negotiation with local ecclesiastic actors. In stark contrast to this picture, no such compromise occurred in Dacia after the evacuation under Aurelian, and contrary to the bordering Ostrogothic organi-

${ }^{36}$ Andrew Poulter. "The Lower Danubian frontier in Late Antiquity: evolution and dramatic change in the frontier zone, c. 296-600.” Zwischen Region und Reich: Das Gebiet der oberen Donau im Imperium Romanum (Berlin: Frank \& Timme, 2010), 11-42.

${ }^{37}$ Delia Moisil. "The Danube Limes and the Barbaricum (294-498 A.D.). A Study in Coin Circulation.” Histoire \& Mesure XVII, 3/4 (2002): 79-120.

${ }^{38}$ Sarah Bassett. The urban image of late antique Constantinople (Cambridge: University Press, 2004).

${ }^{39}$ Gregorio García Herrero. "La reordenación conceptual del territorio en la "Historia Wambae” de Julián de Toledo.” Alebus 6 (1996): 95-112.

${ }^{40}$ Kaiser Reinhold. “Teloneum Episcopi: Du tonlieu royal au tonlieu épiscopal dans les civitates de la Gaule (VIe-XIIe siècle).” Histoire Comparée de l'Administration, Beihefte der Francia 9, ed. Werner Paravicini and Karl Ferdinand Werner (München / Zürich: Artemis, 1980): 469-485.

${ }^{41}$ Stanley Payne. A History of Spain and Portugal, volume 1 (Madison: University of Wisconsin Press, 1973). 
zation under Ermanaric, the Visigoths occupied the Dacian lands as tribes led by chieftains, vaguely and occasionally represented by a iude $x^{42}$, as mentioned above in the case of Athanaric. Only the later proper kingly authority of Alaric would ensure a dynastic structure, tending towards more western regions.

\section{Final remarks}

Although the main chronological indicator for Athanaric's wall does make literary sense on a timeline within generic Gothic brackets, a more conclusive dating might clarify not only the structure itself, but also its articulation with other linear structures such as the so-called Greuthungian wall and other linear earthen fortifications in the areas of modern Moldova and Romania. This paper does not provide a systematization, but it hints at the similar technological and archaeological difficulties that hinder a clear ascription to a moment in time, and to an individual agent. In the case of kingly appropriation of imperial symbols, fiscal, legal and technological solutions, agency becomes a textbook example of context defining social behaviour and daily practice. Yet even for better known linear monuments, such as Hadrian's Wall and its vallum, the promotor's beliefs are not fully understood ${ }^{43}$, and one may describe very well the existing evidence, but not the significance it originally had to the Roman army, apart from self-explanatory historiographic considerations such as defence or territorial control. If the majority of linear fortifications on the Dacian frontier represent exactly the edges of the empire ${ }^{44}$, and some may have even served as a territorial marker only ${ }^{45}$, the suggestion of post- or paraimperial origins for many large defensive works is not unreasonable. An objective look at pre-modern linear barriers concludes for a clear Gothic effort put into permanent earthworks ${ }^{46}$, apart from the temporary ones (e.g. the massive structures Aetius and Theodoric hastily set up in Gaul against Attila (Jord. 37.194), and naturally the plethora of earth-and-palisade perimeters of small settlements, such as hillforts and villages, which are not directly relevant to the present text, although they might include a vallum as well. On the other

\footnotetext{
${ }^{42}$ Jerzy Strzelczyk. "Visigothic Society of the $4^{\text {th }}$ century in the Light of the Passion of Saint Saba the Goth.” Eos 68 (2013): 367-386.

${ }^{43}$ D.J. Breeze, “The Vallum of Hadran's Wall.” Archaeologia Aeliana 5th series 44 (2015): 1-29.

${ }^{44}$ Horațiu Cociș. "Linear Fortifications on the North-Western Frontier of Dacia Porolissensis. An Overview.” Orbis Romanus and Barbaricum, ed. Vitalie Bârcă (Cluj-Napoca: Mega, 2016): 41-54.

${ }^{45}$ J. J. Wilkes. "The Roman Danube: An Archaeological Survey," Journal of Roman Studies 95 (2005): 124-225.

${ }^{46}$ Peter Spring, Great Walls \& Linear Barriers (Barnsley: Pen \& Sword Books, 2015).
} 
hand, Spanish Visigothic defences are mainly circumventing central places such as cities, and the few linear examples are not only exceptional but also reflective of regional power structures, rather than of centralized decisions by the monarchy. They are however important to bear in mind in a comparative light, as their dissimilarity originates not in concept but in context and agency, as the examples of linear, supra-tribal valla are produced by emergencies, not strategic thought, within the boundaries of social beliefs, preconceptions, understanding of the other, and the inherent limitations of place and time.

\section{Rezumat}

Cercetând în principal construcțiile defensive romane târzii și vizigotice din provinciile spaniole, am dat peste detaliile apărării frontierei daco-moesiene mai ales întâmplător, printr-o carte despre Carl Schuchhardt și contribuțiile sale la lucrările de terasare liniare. Aș dori să analizez aceste valuri dintr-un unghi specific, întrucât discuțiile despre valul moldovenesc al lui Athanaric și cronologia acestuia amintesc de întrebările puse și în contextele imperiale de sud-vest. Deși nu se cunosc echivalențe precise pentru astfel de metereze extinse, deseori legate de râuri, în Hispania, doresc să formulez câteva puncte într-o lumină comparativă și să stabilesc câteva corespondențe nu strict arheologice, ci mai degrabă interpretative. Scopul este încadrarea unei meta-analize pentru preocupările defensive gotice timpurii, $\mathrm{cu}$ accent pe structuri mari construite, din punctul de vedere al utilității lor percepute, ca un factor declanșator pentru agenți. În schimb, realitatea culturală a ambelor teritorii este complet distinctă și, prin urmare, poate oferi o abordare interesantă pentru înțelegerea priorităților de investiții în geneza domniilor medievale foarte timpurii și implementarea lor negociată prin mecanisme imperiale transformate. Din nou, aceasta a evoluat pe realități radical separate. Într-un cadru dunărean, se observă o retragere a frontierei asociată cu supraviețuirea politică a imperiului estic; contrar, în Spania, substituirea puterii a reușit doar printr-o negociere permanentă cu puterile locale şi regionale. Studiul de față ia în considerare acest lucru, dar se uită în mod explicit la dimensiunea reactivă, care probabil era preventivă și simbolică, de asemenea, a terasamentelor, valurilor şi a altor forme de apărare liniară postimperială.

Cuvinte cheie: antichitate târzie, sponsorizare, valuri, istorie comparată, administrație gotică.

Adriaan De Man, Department of Tourism and Heritage at the United Arab Emirates University, e-mail: adriaandeman@uaeu.ac.ae 